\title{
Combined pretreatment of sugarcane bagasse using alkali and ionic liquid to increase hemicellulose content and xylanase production
}

\author{
Rozina Rashid ${ }^{1,2}$, Uroosa Ejaz ${ }^{1}$, Firdous Imran Ali ${ }^{3}$, Imran Ali Hashmi ${ }^{3}$, Ahmed Bari ${ }^{4}$, Jing Liư ${ }^{5}$, Li Wang ${ }^{5}$, \\ Pengcheng $\mathrm{Fu}^{5^{*}}$ and Muhammad Sohail ${ }^{1 *}$ (D)
}

\begin{abstract}
Background: Lignin in sugarcane bagasse (SB) hinders its utilization by microorganism, therefore, pretreatment methods are employed to make fermentable components accessible to the microbes. Multivariate analysis of different chemical pretreatment methods can aid to select the most appropriate strategy to valorize a particular biomass.

Results: Amongst methods tested, the pretreatment by using sodium hydroxide in combination with methyltrioctylammonium chloride, an ionic liquid, $(\mathrm{NaOH}+\mathrm{IL})$ was the most significant for xylanase production by Bacillus aestuarii UE25. Investigation of optimal levels of five significant variables by adopting Box-Behnken design (BBD) predicted $20 \mathrm{IU} \mathrm{mL} \mathrm{mL}^{-1}$ of xylanase and experimentally, a titer of $17.77 \mathrm{IU} \mathrm{mL} \mathrm{m}^{-1}$ was obtained which indicated the validity of the model. The production kinetics showed that volumetric productivity of xylanase was much higher after $24 \mathrm{~h}$ (833.33 $\left.\mathrm{IU} \mathrm{L} \mathrm{L}^{-1} \mathrm{~h}^{-1}\right)$ than after $48 \mathrm{~h}\left(567.08 \mathrm{IU} \mathrm{L} \mathrm{L}^{-1} \mathrm{~h}^{-1}\right)$. The extracted xylan from SB induced more xylanase in the fermentation medium than pretreated SB or commercially purified xylan. Nuclear Magnetic Resonance, Fourier transform infrared spectroscopy and scanning electron microscopy of SB indicated removal of lignin and changes in the structure of SB after $\mathrm{NaOH}+\mathrm{IL}$ pretreatment and fermentation.

Conclusion: Combined pretreatment of SB with alkali and methyltrioctylammonium chloride appeared better than other chemical methods for bacterial xylanase production and for the extraction of xylan form SB.
\end{abstract}

Keywords: Bacillus aestuarii, Ionic liquid, FTIR, NMR, Pretreatment,Xylan

\section{Background}

Sugarcane bagasse $(\mathrm{SB})$ is one of the abundant, low-cost agricultural deposits in the world which is mainly composed of lignin, hemicellulose, cellulose, wax and ash [1]. Owing to its site availability at sugar industries, SB can be used to generate additional revenues by utilizing it for the synthesis of chemicals, fuels and enzymes [2]. Pakistan,

\footnotetext{
* Correspondence: pcfu@hainu.edu.cn; msohail@uok.edu.pk

'Department of Microbiology, University of Karachi, 75270, Karachi, Pakistan ${ }^{5}$ State Key Laboratory of Marine Resource Utilization in South China Sea, Hainan University, Haikou 570228, China

Full list of author information is available at the end of the article
}

China, Mexico, India, Philippines, Thailand and Brazil are the major sugarcane producing countries [3] and therefore, can be befitted by adopting SB-based technologies. SB is a polysaccharides rich waste and hence a promising raw material in context of biorefineries [4] which can be utilized in various transformation processes. Therefore, the advances in biorefineries from SB have been investigated in numerous studies, with an immense range of configurations [5]. Sugar monomers like xylose and glucose can be obtained from SB which can be utilized in fermentation process to

(c) The Author(s). 2020 Open Access This article is licensed under a Creative Commons Attribution 4.0 International License, which permits use, sharing, adaptation, distribution and reproduction in any medium or format, as long as you give appropriate credit to the original author(s) and the source, provide a link to the Creative Commons licence, and indicate if changes were made. The images or other third party material in this article are included in the article's Creative Commons licence, unless indicated otherwise in a credit line to the material. If material is not included in the article's Creative Commons licence and your intended use is not permitted by statutory regulation or exceeds the permitted use, you will need to obtain permission directly from the copyright holder. To view a copy of this licence, visit http://creativecommons.org/licenses/by/4.0/ The Creative Commons Public Domain Dedication waiver (http://creativecommons.org/publicdomain/zero/1.0/) applies to the data made available in this article, unless otherwise stated in a credit line to the data. 
produce xylitol, lactic acid, ethanol, succinic acid, biopolymers, arabitol, electricity and antioxidants $[3,6]$.

Since presence of lignin and crystalline cellulose impedes microbial degradation of SB, therefore, pretreatment processes are universally adopted prior to utilization of the substrate in fermentation. A successful pretreatment or delignification enhances porosity, decreases polymerization and crystallinity of biomass, which elevates the accessibility of xylanases towards xylan [7]. Reports suggest that alkaline pretreatment of $\mathrm{SB}$ is better than acid $\left(\mathrm{H}_{2} \mathrm{SO}_{4}\right)$ pretreatment as $\mathrm{NaOH}$ can dissolve more lignin in $\mathrm{SB}$ than $\mathrm{H}_{2} \mathrm{SO}_{4}$ [8]. Hydrogen peroxide [9] and ionic liquids (ILs) are other solvents that have also been employed for pretreatment of biomass. In comparison to other solvents, ILs show valuable properties including non-combustibility, lower toxicity and low vapor pressure [10, 11]. ILs convert crystalline components into amorphous forms that can easily be degraded because of the presence of more active sites. However, the selection of pretreatment methods depends on a number of factors including economic and environmental aspects. Ávila et al. [12] statistically compared the effectiveness of two pretreatment methods of SB namely, dilute acid and 1-ethyl-3methylimidazolium acetate and utilized the pretreated substrate for the enzymatic hydrolysis to produce xylooligosacchaarides. Imidazolium-based ILs have been applied frequently, however, these are reportedly less biodegradable and harmful to the environment as well as to the aquatic organisms due to their toxic effects similar to chemicals (e.g., ammonia and phenol) used in disinfection processes [13]. Studies suggest that using such ILs under basic conditions may cause unexpected side reactions [14]. Therefore, an ammonium-based IL, methyltrioctylammonium chloride, was used in the current study. It is a water insoluble salt with low melting point and less viscosity [15]. The pretreatment of SB with this IL has been reported recently for the production of cellulases from thermophilic bacteria [15], therefore, it was tested to investigate its effectiveness in subsequent xylan extraction from SB. Considering the important component of lignocellulose (LC), xylan recovery from $\mathrm{SB}$ is a strategy to use hemicellulose component with commercial applicability. Current examples of industrial uses of xylan include in paper making, biomedical products, food products coating and packaging films [16]. The major limitation to the large scale hydrolysis of xylan is the cost of xylanase production. Xylan present in SB induces xylanase production [17], therefore, SB can serves as a promising feedstock for this purpose. In the current years, xylanase has acquired great attention due to its wide-ranging biotechnological uses. This enzyme is potentially applied to industries for bioconversion of hemicelluloses to xylose, clarification of juices and wines, de-inking processes of waste paper, textile and leather, refining the nutritional value of silage and fodder, agricultural waste treatment, paper and pulp industries, pharmaceuticals, ethanol and other useful substances [17].
Many of these processes employ thermostable xylanases that can withstand extreme process conditions.

Thermophiles are considered as cell factories for industrially important thermostable enzymes. The reactions by these enzymes at high temperature permit better solubility of reactants prompting faster hydrolysis [18]. B. aestuarii has previously been reported for the xylanase production by utilizing commercially available substrates [19]. To the best of our knowledge this is the first report on xylanase production by $B$. aestuarii using IL pretreated SB with the aid of a sequential and statistical optimization method. The main objective of the present study was to chemically pretreat SB in cost effective way so that lignin is removed and hemicellulosic content becomes available for fermentation purpose. Xylan was also extracted from pretreated SB and compared with commercially available substrate. The structural changes in SB after pretreatment and fermentation were recorded by nuclear magnetic resonance spectroscopy, Fourier transform infrared spectroscopy and scanning electron microscopy.

\section{Results}

Screening of thermophilic strains for xylanase production Four thermophilic bacterial strains including Aneurinibacillus thermoaerophilus UE1, Brevibacillus borstelensis UE10, Brevibacillus borstelensis UE27 and B. aestuarii UE25 were initially screened for xylanase production by utilizing untreated and pretreated SB at different temperatures. $A$. thermoaerophilus UE1 did not produce any enzyme on hydrogen peroxide pretreated $\mathrm{SB}$, however, it yielded the titers as high as $4.55 \mathrm{IU} \mathrm{mL}^{-1}$ at $60^{\circ} \mathrm{C}$ cultivation on other chemically treated SB (Supplementary Table S2) reflecting thermophilic nature of the strain. Likewise, B. borstelensis UE27 produced higher titers of xylanase at $60^{\circ} \mathrm{C}$ than at $55^{\circ} \mathrm{C}$. B. borstelensis UE10 did not exhibit any xylanolytic activity and hence was found incapable of utilizing SB at mentioned temperatures. Nonetheless, B. aestuarii UE25 appeared as the most promising strain as it produced $18.38 \mathrm{IU}$ $\mathrm{mL}^{-1}$ at $60^{\circ} \mathrm{C}$. The strain was also cultivated at $37^{\circ} \mathrm{C}$ to observe any effect of temperature on the xylanase production, however, a lower productivity $\left(14.92 \mathrm{IU} \mathrm{mL}^{-1}\right)$ was noted (Supplementary Table S3) and hence the strain was cultivated at higher temperature in subsequent experiments.

\section{Evaluation of alkali and IL pretreatment of SB for xylanase production}

The factors affecting xylanase production by $B$. aestuarii UE25 on pretreated SB were evaluated by a statistical method, PBD (Table 1). Among the three separate experimental designs performed, the data of the design 3 (for " $\mathrm{H}_{2} \mathrm{O}_{2}$ /Untreated" SB) revealed that xylanase titers of 10.2 $\mathrm{IU} \mathrm{mL} \mathrm{m}^{-1}$ can be obtained using $\mathrm{H}_{2} \mathrm{O}_{2}$ pretreated $\mathrm{SB}$ (Table 2). However, this productivity was much lower than observed in response to the experiments performed for the design $2\left(\mathrm{NaOH} / \mathrm{H}_{2} \mathrm{SO}_{4}\right)$ and the design $1(\mathrm{IL} / \mathrm{NaOH}+\mathrm{IL})$. 
Table 1 Plackett Burman experimental design (PBD) for xylanase production by using different pretreated sugarcane bagasse

\begin{tabular}{|c|c|c|c|c|c|c|c|c|c|c|}
\hline \multirow[t]{2}{*}{ Run Order } & \multicolumn{3}{|c|}{ Bagasse pretreatment } & \multirow[t]{2}{*}{ Medium* } & \multirow{2}{*}{$\begin{array}{l}\text { Incubation } \\
\text { temperature }\left({ }^{\circ} \mathrm{C}\right)\end{array}$} & \multirow[t]{2}{*}{$\mathrm{pH}$} & \multirow{2}{*}{$\begin{array}{l}\text { Substrate } \\
\text { concentration(\%) }\end{array}$} & \multirow[t]{2}{*}{ Inoculumsize (\%) } & \multirow{2}{*}{$\begin{array}{l}\text { Incubation } \\
\text { time (h) }\end{array}$} & \multirow{2}{*}{$\begin{array}{l}\text { Agitation } \\
\text { (150 rpm) }\end{array}$} \\
\hline & PBD 1 & PBD 2 & PBD 3 & & & & & & & \\
\hline 1 & $\mathrm{NaOH}+\mathrm{IL}^{\mathrm{a}}$ & $\mathrm{NaOH}^{\mathrm{b}}$ & $\mathrm{H}_{2} \mathrm{O}_{2}{ }^{\mathrm{C}}$ & $\mathrm{MSM}+0.5 \% \mathrm{G}$ & 60 & 5 & 1 & 5 & 48 & without \\
\hline 2 & $\mathrm{NaOH}+\mathrm{IL}$ & $\mathrm{NaOH}$ & $\mathrm{H}_{2} \mathrm{O}_{2}$ & $\mathrm{MSM}+0.5 \mathrm{G} \& \mathrm{P}$ & 55 & 7 & 1 & 5 & 24 & without \\
\hline 3 & $\mathrm{IL}^{\mathrm{d}}$ & $\mathrm{H}_{2} \mathrm{SO}_{4}{ }^{\mathrm{e}}$ & $\mathrm{UTB}^{f}$ & $\mathrm{MSM}+0.5 \mathrm{G} \& \mathrm{P}$ & 60 & 5 & 2 & 5 & 24 & with \\
\hline 4 & $\mathrm{NaOH}+\mathrm{IL}$ & $\mathrm{NaOH}$ & $\mathrm{H}_{2} \mathrm{O}_{2}$ & $\mathrm{MSM}+0.5 \% \mathrm{G}$ & 60 & 7 & 1 & 10 & 24 & with \\
\hline 5 & $\mathrm{NaOH}+\mathrm{IL}$ & $\mathrm{NaOH}$ & $\mathrm{H}_{2} \mathrm{O}_{2}$ & $\mathrm{MSM}+0.5 \mathrm{G} \& \mathrm{P}$ & 55 & 7 & 2 & 5 & 48 & with \\
\hline 6 & $\mathrm{NaOH}+\mathrm{IL}$ & $\mathrm{NaOH}$ & $\mathrm{H}_{2} \mathrm{O}_{2}$ & $\mathrm{MSM}+0.5 \mathrm{G} \& \mathrm{P}$ & 60 & 5 & 2 & 10 & 24 & without \\
\hline 7 & $\mathrm{IL}$ & $\mathrm{H}_{2} \mathrm{SO}_{4}$ & UTB & $\mathrm{MSM}+0.5 \mathrm{G} \& \mathrm{P}$ & 60 & 7 & 1 & 10 & 48 & with \\
\hline 8 & IL & $\mathrm{H}_{2} \mathrm{SO}_{4}$ & UTB & $\mathrm{MSM}+0.5 \% \mathrm{G}$ & 60 & 7 & 2 & 5 & 48 & without \\
\hline 9 & IL & $\mathrm{H}_{2} \mathrm{SO}_{4}$ & UTB & $\mathrm{MSM}+0.5 \% \mathrm{G}$ & 55 & 7 & 2 & 10 & 24 & without \\
\hline 10 & $\mathrm{NaOH}+\mathrm{IL}$ & $\mathrm{NaOH}$ & $\mathrm{H}_{2} \mathrm{O}_{2}$ & $\mathrm{MSM}+0.5 \% \mathrm{G}$ & 55 & 5 & 2 & 10 & 48 & with \\
\hline 11 & IL & $\mathrm{H}_{2} \mathrm{SO}_{4}$ & UTB & $\mathrm{MSM}+0.5 \mathrm{G} \& \mathrm{P}$ & 55 & 5 & 1 & 10 & 48 & without \\
\hline 12 & $\mathrm{IL}$ & $\mathrm{H}_{2} \mathrm{SO}_{4}$ & UTB & $\mathrm{MSM}+0.5 \% \mathrm{G}$ & 55 & 5 & 1 & 5 & 24 & with \\
\hline
\end{tabular}

* MSM Mineral salt medium, $G$ Glucose, $P$ Peptone

$a=$ alkali + ionic liquid, $b=$ alkali, $c=$ hydrogen peroxide, $d=$ ionic liquid, $e=$ acid, $f=$ untreated bagasse.

This observation may be attributed to the disadvantage of using $\mathrm{H}_{2} \mathrm{O}_{2}$ which causes lesser degree of delignification. The data obtained for " $\mathrm{NaOH} / \mathrm{H}_{2} \mathrm{SO}_{4}$ " pretreated SB revealed that the response was higher (more xylanase produced) from the experiments where alkali pretreated SB was used. The design for $\mathrm{NaOH}+\mathrm{IL} / \mathrm{IL}$ (pretreatment of SB by $\mathrm{NaOH}$ followed by IL or pretreatment by IL alone) was found to be the most striking as the highest titers of 37.48 $\mathrm{IU} \mathrm{mL}{ }^{-1}$ of xylanase was obtained in one of the experiment where $5 \%$ inoculum was transferred to the medium of $\mathrm{pH}$ 7, containing $1 \%$ pretreated SB and MSM supplemented with $0.5 \%$ glucose and peptone and incubated for $24 \mathrm{~h}$ without agitation which indicated the effectiveness of using $\mathrm{NaOH}$ and IL for the pretreatment of SB.
The regression analysis of the response (Supplementary Table S4), ANOVA (Supplementary Table S5) and Pareto chart (Supplementary Fig. S1) for the design 1 illustrated that five of the factors including inoculum size, incubation time, temperature, agitation and $\mathrm{pH}$ were significant for the xylanase production with $P$-value $<0.05$. The analysis of the design 2 indicated four significant factors, including pretreatment, incubation period, $\mathrm{pH}$ and inoculum size (Supplementary Table S6, S7), while the design 3 revealed significance of three important factors namely $\mathrm{pH}$, cultivation temperature and incubation period (Supplementary Table S8, S9). Nonetheless, one of these designs had to be selected for the optimization using response surface methodology. Since the xylanase titers obtained in the

Table 2 Xylanase response by Plackett Burman experimental design

\begin{tabular}{|c|c|c|c|}
\hline \multirow[t]{2}{*}{ Run order } & \multicolumn{3}{|c|}{ Xylanase (IU mL $\left.{ }^{-1}\right)$ obtained from different pretreated sugarcane bagasse } \\
\hline & $\mathrm{IL} / \mathrm{NaOH}+\mathrm{IL}$ & $\mathrm{NaOH} / \mathrm{H}_{2} \mathrm{SO}_{4}$ & $\mathrm{H}_{2} \mathrm{O}_{2} / \mathrm{UTB}$ \\
\hline 1 & $10.72 \pm 0.65$ & $15.92 \pm 1.95$ & $10.2 \pm 0.84$ \\
\hline 2 & $37.48 \pm 2.7$ & $4.96 \pm 0.38$ & 0 \\
\hline 3 & $7.21 \pm 0.07$ & $11.4 \pm 0.22$ & 0 \\
\hline 4 & $15.45 \pm 0.56$ & 0 & 0 \\
\hline 5 & $19.26 \pm 0.03$ & 0 & $5.76 \pm 0.58$ \\
\hline 6 & $9.32 \pm 0.02$ & $9.22 \pm 0.09$ & 0 \\
\hline 7 & $4.92 \pm 0.01$ & 0 & 0 \\
\hline 8 & $12.90 \pm 0.04$ & $6.64 \pm 0.57$ & 0 \\
\hline 9 & $26.57 \pm 0.09$ & $6.29 \pm 0.04$ & 0 \\
\hline 10 & $13.90 \pm 0.04$ & $5.94 \pm 0.04$ & $10.2 \pm 0.35$ \\
\hline 11 & $14.87 \pm 0.035$ & $11.45 \pm 0.04$ & $7.71 \pm 0.13$ \\
\hline 12 & $22.10 \pm 0.12$ & $15.92 \pm 0.75$ & $7.19 \pm 0.04$ \\
\hline
\end{tabular}


experiments suggested by the design 1 were apparently higher than the other designs therefore, it was hypothesized that the mean IU mL $\mathrm{mL}^{-1}$ obtained for the design 1 was greater than the design 2 and the design 3. In order to statistically prove, the data from PBDs was compared by Two-way ANOVA. The model for $\mathrm{NaOH}+\mathrm{IL}$ was found significant for pretreatment of $\mathrm{SB}$ and xylanase production with $\mathrm{F}$-value $>\mathrm{F}$-critical value and $P$-value $<0.05$ for the columns (Supplementary Table S10).

\section{Optimization of xylanase production by fermention of $\mathrm{NaOH}+\mathrm{IL}$ pretreated $\mathrm{SB}$}

The important factors influencing the xylanase production by $B$. aestuarii UE25 on $\mathrm{NaOH}+\mathrm{IL}$ pretreated $\mathrm{SB}$ were further optimized by BBD through RSM approach. Five significant factors i.e. inoculum size, incubation time, temperature, agitation and $\mathrm{pH}$ (at three levels; -1 , $0,+1$ ) were studied in 46 experimental runs as proposed by BBD (Table 3). Xylanase titers acquired by BBD experiments were analyzed by ANOVA. The model presented an $\mathrm{R}^{2}$ value of $86.28 \%$ (Supplementary Table S11) indicating that the total variation of $86.28 \%$ was imputed to the factors in the model. Furthermore, the $p$-value $(\leq 0.05)$ and F-value (17.29) indicated the significance of the model. A response optimization experiment was proposed by the software at optimum conditions of temperature, $59.8^{\circ} \mathrm{C}$; inoculum size, $7.03 \%$; $\mathrm{pH}, 5$; agitation, $141 \mathrm{rpm}$ and incubation period, $24 \mathrm{~h}$. Under these optimal conditions, $17.77 \mathrm{IU} \mathrm{mL}^{-1}$ of xylanase titers were obtained, in comparison to the predicted value of $20 \mathrm{IU} \mathrm{mL}^{-1}$ indicating the validity of the model. The results from the data showed that the B. aestuarii UE25 could produce optimal xylanase titers after $24 \mathrm{~h}$ into fermentation medium with $\mathrm{pH} 5$ by inoculating $7.03 \%$ culture, incubating at $59.8^{\circ} \mathrm{C}$ with agitation rate $141 \mathrm{rpm}$.

Interaction between the factors affecting xylanase production was studied against two independent variables and the optimal values were calculated by contour plots (Fig. 1). Interaction of temperature with $\mathrm{pH}$ was insignificant but the interaction of temperature and inoculum size was found to be statistically significant; when the inoculum size at $60^{\circ} \mathrm{C}$ is kept $10 \%$, xylanase production can be improved. The interactive effect of temperature and incubation time also appeared significant. Main effects indicate that increase in incubation time (up to $48 \mathrm{~h}$ ) and temperature $\left(60^{\circ} \mathrm{C}\right.$ ) result in enhanced xylanase production. Xylanase titer increased with an increase in the inoculum size (up to $10 \%$ ) when agitation rate was $140 \mathrm{rpm}$. A decrease in xylanase titer was observed when inoculum size was increased with $\mathrm{pH}$, whereas agitation had a positive effect on xylanase production at $\mathrm{pH} 6.5-7.0$.

\section{Kinetics of xylanase production}

The results (Fig. 2) showed that B. aestuarii UE25 exhibited $20 \mathrm{IU} \mathrm{mL}^{-1}$ after $24 \mathrm{~h}$ incubation and $27.22 \mathrm{IU} \mathrm{mL}^{-1}$ after $49 \mathrm{~h}$ of incubation. To evaluate the titers obtained in $49 \mathrm{~h}$ in comparison to $24 \mathrm{~h}$, productivity parameters were compared. The volumetric productivity $\left(\mathrm{Q}_{\mathrm{p}}\right)$ for xylanase was found to be $833.33 \mathrm{IU} \mathrm{L}^{-1} \mathrm{~h}^{-1}$ in $24 \mathrm{~h}$ and $567.08 \mathrm{IU}$ $\mathrm{L}^{-1} \mathrm{~h}^{-1}$ in $48 \mathrm{~h}$. Further increase in the fermentation time $(72 \mathrm{~h})$ resulted in decreased xylanase production. The drop in the yield of xylanase was probably due to the reduction of nutrients or proteolysis. Initially no change in $\mathrm{pH}$ was observed during cultivation, then after $48 \mathrm{~h}$ a drop in $\mathrm{pH}$ was noted that was coupled with a slight increase in the xylanase titers. Reduction in the medium $\mathrm{pH}$ was may be due to xylan hydrolysis (liberation of some monosaccharides causes the $\mathrm{pH}$ to reduce) [20] or acid produced during the fermentation process [21] and it indicated that the metabolism was not shifted towards proteolysis.

\section{Extraction of xylan from SB}

Chemical composition of untreated sugarcane bagasse (used in this study) was investigated by Ejaz et al. [22] and presence of $30.8 \%$ xylan was reported in untreated sugarcane bagasse. In this study, xylan was extracted from $\mathrm{NaOH}+\mathrm{IL}$ pretreated SB. Pretreated SB resulted in $45 \%$ yield of xylan whereas untreated SB resulted in $18.12 \%$ xylan. Higher xylanase production (1.25 fold) was noted after the fermentation of extracted xylan (from pretreated $\mathrm{SB}$ ) than the commercially purified $\mathrm{xy}$ lan (Table 4). Along with xylanases, EG, BGL and FPase assays were also performed. Increased IU $\mathrm{mL}^{-1}$ for EG (from 21.95 to 36.06) and BGL (from 34.49 to 35.8) was obtained after $24 \mathrm{~h}$ of fermentation as compared to commercial xylan which indicated that cellulase and xylanase have the characteristics of co-expression.

\section{Scanning Electron microscopy}

SEM images at 1000X magnification of the untreated SB samples (Supplementary Fig. S2a) showed highly ordered, compact and thick-walled fibers. Whereas, $\mathrm{NaOH}+\mathrm{ILpre-}$ treatment resulted in significant changes in structure of SB. SEM of pretreated SB sample (Supplementary Fig. $\mathrm{S} 2 \mathrm{~b})$ shows that fibrils became more exposed by the removal of the superficial layer due to $\mathrm{NaOH}+\mathrm{IL}$ pretreatment and the contact area was increased. It can be seen that the SmF of SB (Supplementary Fig. S2c) caused destruction and separation of fibers, which clearly showed the enzymatic degradation of SB.

\section{Fourier transform infrared (FTIR) spectroscopy analysis}

FTIR spectra were studied for pretreated and fermented SB and the data was correlated with the untreated SB as given by Ejaz et al. [22]. In pretreated SB (Fig. 3a), the removal of lignin was evident by the changes in the region 
Table 3 Box-Behnken design for xylanase production by Bacillus aestuarii UE25

\begin{tabular}{|c|c|c|c|c|c|c|}
\hline Run Order & Temperature $\left({ }^{\circ} \mathrm{C}\right)$ & Incubation time (h) & $\mathrm{pH}$ & Agitation (rpm) & Inoculum size (\%) & Xylanase production $\left(\mathrm{IU} \mathrm{mL}^{-1}\right)^{\mathrm{a}}$ \\
\hline 1 & 55 & 24 & 6 & 75 & 7.5 & 0 \\
\hline 2 & 60 & 24 & 6 & 75 & 7.5 & 14.20 \\
\hline 3 & 55 & 72 & 6 & 75 & 7.5 & 7.13 \\
\hline 4 & 60 & 72 & 6 & 75 & 7.5 & 9.15 \\
\hline 5 & 57.5 & 48 & 5 & 0 & 7.5 & 6.69 \\
\hline 6 & 57.5 & 48 & 7 & 0 & 7.5 & 17.95 \\
\hline 7 & 57.5 & 48 & 5 & 150 & 7.5 & 13.32 \\
\hline 8 & 57.5 & 48 & 7 & 150 & 7.5 & 11.79 \\
\hline 9 & 57.5 & 24 & 6 & 75 & 5 & 11.70 \\
\hline 10 & 57.5 & 72 & 6 & 75 & 5 & 9.59 \\
\hline 11 & 57.5 & 24 & 6 & 75 & 10 & 12.41 \\
\hline 12 & 57.5 & 72 & 6 & 75 & 10 & 12.76 \\
\hline 13 & 55 & 48 & 5 & 75 & 7.5 & 0 \\
\hline 14 & 60 & 48 & 5 & 75 & 7.5 & 6.74 \\
\hline 15 & 55 & 48 & 7 & 75 & 7.5 & 6.86 \\
\hline 16 & 60 & 48 & 7 & 75 & 7.5 & 9.33 \\
\hline 17 & 57.5 & 48 & 6 & 0 & 5 & 10.12 \\
\hline 18 & 57.5 & 48 & 6 & 150 & 5 & 20.17 \\
\hline 19 & 57.5 & 48 & 6 & 0 & 10 & 30.10 \\
\hline 20 & 57.5 & 48 & 6 & 150 & 10 & 12.76 \\
\hline 21 & 57.5 & 24 & 5 & 75 & 7.5 & 7.74 \\
\hline 22 & 57.5 & 72 & 5 & 75 & 7.5 & 8.09 \\
\hline 23 & 57.5 & 24 & 7 & 75 & 7.5 & 8.36 \\
\hline 24 & 57.5 & 72 & 7 & 75 & 7.5 & 7.39 \\
\hline 25 & 55 & 48 & 6 & 0 & 7.5 & 11.03 \\
\hline 26 & 60 & 48 & 6 & 0 & 7.5 & 14.96 \\
\hline 27 & 55 & 48 & 6 & 150 & 7.5 & 11.53 \\
\hline 28 & 60 & 48 & 6 & 150 & 7.5 & 22.26 \\
\hline 29 & 57.5 & 48 & 5 & 75 & 5 & 8.85 \\
\hline 30 & 57.5 & 48 & 7 & 75 & 5 & 8.80 \\
\hline 31 & 57.5 & 48 & 5 & 75 & 10 & 9.76 \\
\hline 32 & 57.5 & 48 & 7 & 75 & 10 & 6.92 \\
\hline 33 & 55 & 48 & 6 & 75 & 5 & 0 \\
\hline 34 & 60 & 48 & 6 & 75 & 5 & 16.54 \\
\hline 35 & 55 & 48 & 6 & 75 & 10 & 15.84 \\
\hline 36 & 60 & 48 & 6 & 75 & 10 & 12.76 \\
\hline 37 & 57.5 & 24 & 6 & 0 & 7.5 & 11.35 \\
\hline 38 & 57.5 & 72 & 6 & 0 & 7.5 & 16.90 \\
\hline 39 & 57.5 & 24 & 6 & 150 & 7.5 & 8.69 \\
\hline 40 & 57.5 & 72 & 6 & 150 & 7.5 & 16.66 \\
\hline 41 & 57.5 & 48 & 6 & 75 & 7.5 & 6.87 \\
\hline 42 & 57.5 & 48 & 6 & 75 & 7.5 & 8.09 \\
\hline 43 & 57.5 & 48 & 6 & 75 & 7.5 & 5.87 \\
\hline 44 & 57.5 & 48 & 6 & 75 & 7.5 & 7.92 \\
\hline
\end{tabular}


Table 3 Box-Behnken design for xylanase production by Bacillus aestuarii UE25 (Continued)

\begin{tabular}{|c|c|c|c|c|c|c|}
\hline Run Order & Temperature $\left({ }^{\circ} \mathrm{C}\right)$ & Incubation time (h) & $\mathrm{pH}$ & Agitation (rpm) & Inoculum size (\%) & Xylanase production (IU $\left.\mathrm{mL}^{-1}\right)^{\mathrm{a}}$ \\
\hline 45 & 57.5 & 48 & 6 & 75 & 7.5 & 8.62 \\
\hline 46 & 57.5 & 48 & 6 & 75 & 7.5 & 7.50 \\
\hline
\end{tabular}

${ }^{\mathrm{a}}$ With insignificant standard deviation

of $1260.93 \mathrm{~cm}^{-1}$. The noticeable changes in the region associated with lignin from $1425.39 \mathrm{~cm}^{-1}$ to $1511.93 \mathrm{~cm}^{-1}$ [23] were also observed. The effect on lignin moiety was also visible by the change in the region of $3420.48 \mathrm{~cm}^{-1}$. The FTIR spectra revealed presence of cellulose and hemicellulose components in pretreated SB by highlighting asymmetrical stretching of $\mathrm{CH}_{2}$ and $\mathrm{CH}$ of cellulose [24] at $2918.46 \mathrm{~cm}^{-1}$ and the changes in the regions at $1109.77 \mathrm{~cm}^{-1}$ and $1161.31 \mathrm{~cm}^{-1}$ by hemicelluloses [25]. Moreover, $\beta$-glycosidic linkages between xylose units were observed at $897.90 \mathrm{~cm}^{-1}$ [16].

The effects of fermentation on pretreated SB (Fig. 3b) were evident in the region between $1057 \mathrm{~cm}^{-1}$ and $1162.04 \mathrm{~cm}^{-1}$ that indicated the hydrolysis of hemicellulose and cellulose. A characteristic band at $897.76 \mathrm{~cm}^{-1}$ for $\beta$ $(1 \rightarrow 4)$ glycosidic bond [26] was also present. The change in the stretching of $\mathrm{C}=\mathrm{O}$ of hemicellulose and lignin was observed by the band at $1244.79 \mathrm{~cm}^{-1}$ [27]. Presence of methoxy group due to acetyl portion of hemicellulose was visible by the band at $2855.92 \mathrm{~cm}^{-1}$. The changes in the region of $2855.92 \mathrm{~cm}^{-1}$ and $2925.79 \mathrm{~cm}^{-1}$ revealed changes in cellulosic content of SB [24].

The structure of the extracted xylan from untreated (Fig. 3c) and pretreated (Fig. 3d) SB was also evaluated by FTIR analysis. The peaks at 3419, 2920, 1636, 1464, 1419, 1384, 1248, 1163, 1043 and $898 \mathrm{~cm}^{-1}$ are assigned to hemicelluloses [27]. The $\mathrm{C}-\mathrm{O}, \mathrm{C}-\mathrm{C}$ stretching or C$\mathrm{OH}$ bending in the sugar units was observed as a sharp (a)

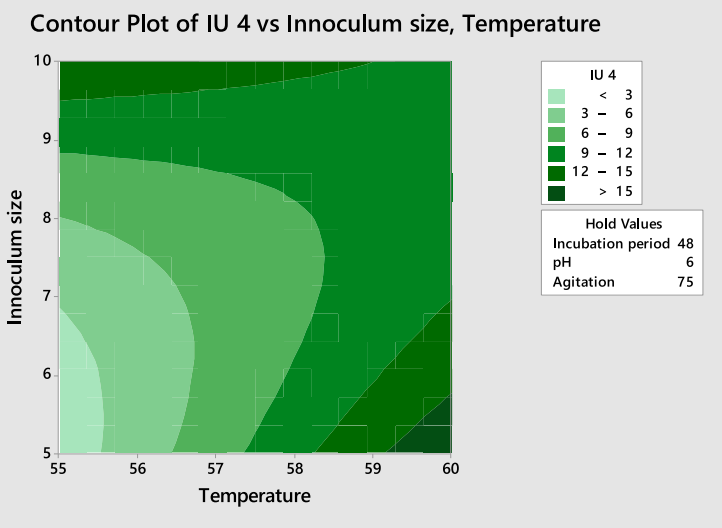

(b)

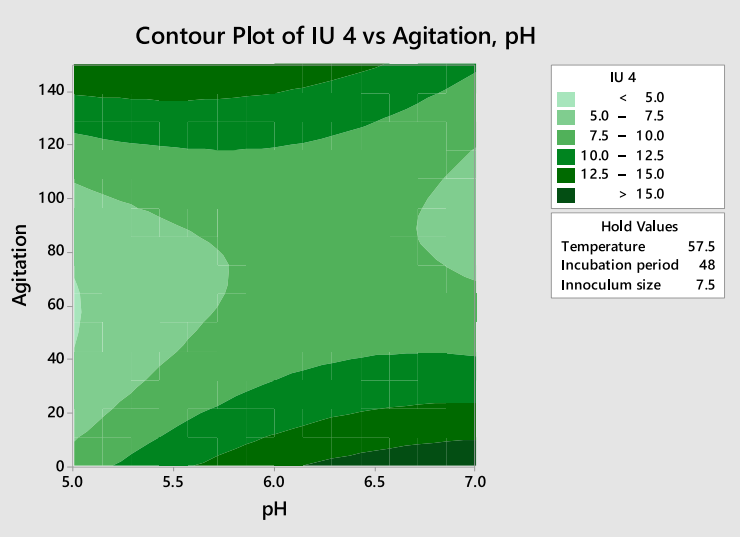

(c)

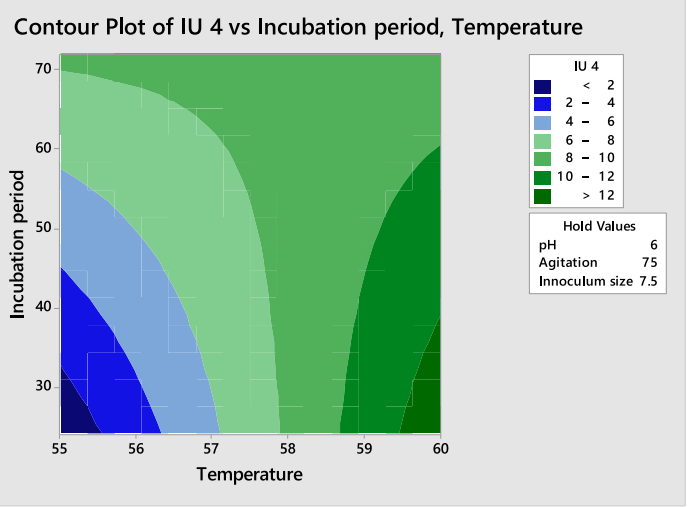

(d)

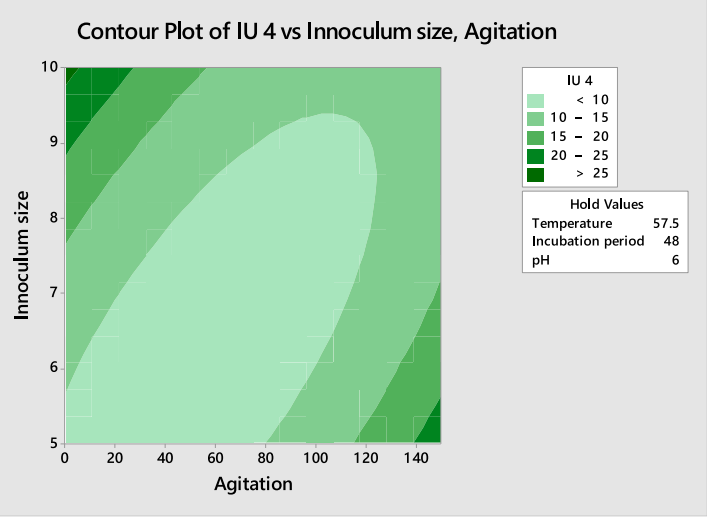

Fig. 1 Contour Plot showing interaction of (a) Inoculum size and Temperature (b) Agitation and pH (c) Incubation period and Temperature (d) Inoculum size and Agitation on xylanase production by Bacillus aestuarii UE25 


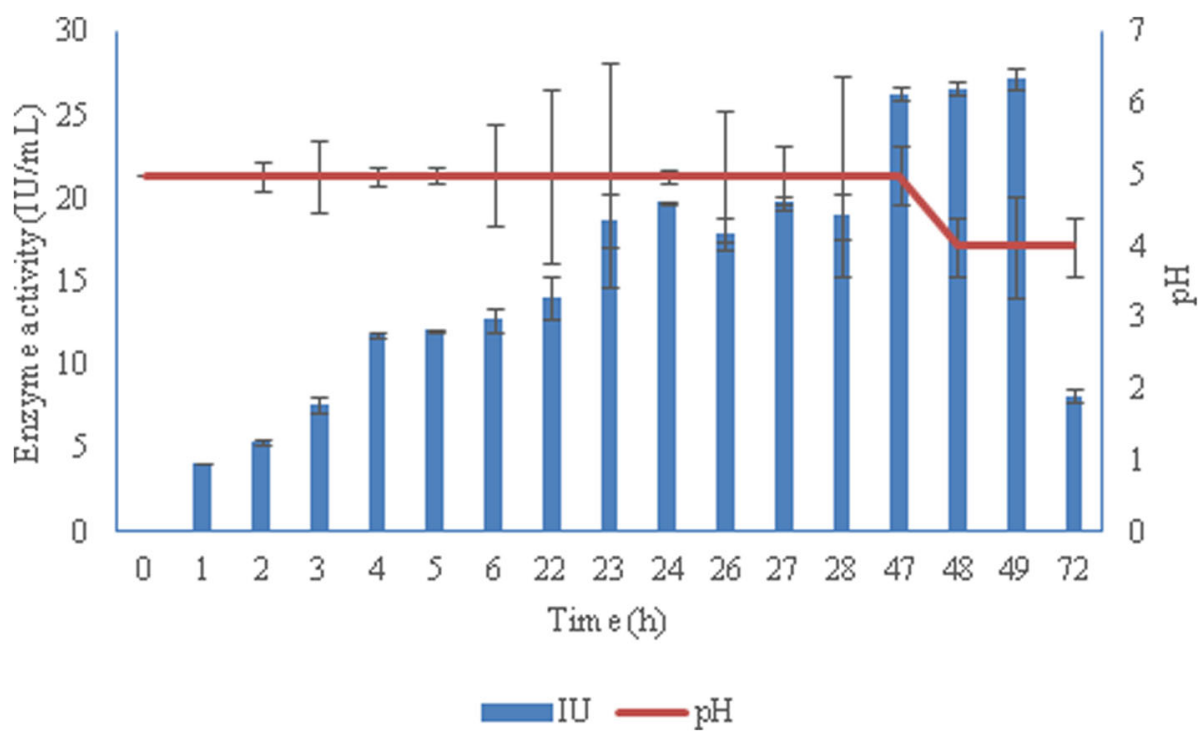

Fig. 2 Time course study and effect of pH on production of xylanase by Bacillus aestuarii UE25

band at $1043 \mathrm{~cm}^{-1}$, whereas, a sharp band at 896.27 $\mathrm{cm}^{-1}$ presented the dominance of $\beta$-glycosidic linkages between the xylose units. A slight change was observed in the region of $894.84 \mathrm{~cm}^{-1}$ for the untreated SB along with the absorption at $1636 \mathrm{~cm}^{-1}$. The observation was further complemented by the spectra at $2920 \mathrm{~cm}^{-1}$ and $2921 \mathrm{~cm}^{-1}$ that were attributed to the $\mathrm{C}-\mathrm{H}$ stretching vibrations caused by the water involved in the hydrogen bonding in xylan [22]. The quality of the extracted xylan was highlighted by the absence of absorbance at around $1720 \mathrm{~cm}^{-1}$ that is otherwise observed if xylan is oxidized to ketone and carbonyls [28].

\section{Nuclear magnetic resonance (NMR) spectroscopy of SB}

NMR spectroscopic technique is a rapid and sensitive technique to obtain information about small changes in certain chemical groups. ${ }^{1} \mathrm{H}$ NMR spectroscopy technique was utilized to obtain information about the changes occurring in the SB samples before and after treatment with alkali and IL. The signals in the H NMR spectrum in the range of 6.0-6.5 are assigned to aromatic regions in lignin. The absence of aromatic proton peaks in $\mathrm{NaOH}+\mathrm{IL}$ treated (Fig. 4a) and fermented (Fig. 4b) SB in the same range indicates the cleavage of $\beta-O-4$ linkage and decomposition or removal of the lignin part [29]. The signals in H NMR spectrum of untreated SB in the range 5.3 to 5.8 exhibit the $\mathrm{H} \beta$ in benzyl aryl ether which is a functional group present in lignin [30]. In contrast, spectra of pretreated SB do not show any signals in this region indicating degradation or removal of lignin in pretreated SB. The fewer peaks in the spectra of both the samples in the range 4.5-4.8 ppm show the absence of $\mathrm{Hy}$ in $\beta-\mathrm{O}-4$ aryl ether which is a characteristic of lignin [28]. The signals in the range of 3.0 to $4.5 \mathrm{ppm}$ are assigned to the methoxyl

Table 4 Xylanase and cellulase production by Bacillus aestuarii UE25 using extracted xylan

\begin{tabular}{|c|c|c|c|c|c|c|c|c|}
\hline \multirow[t]{3}{*}{ Substrate $^{a}$} & \multicolumn{8}{|c|}{ Enzyme productivity $\left(\mathrm{IU} \mathrm{mL}^{-1}\right)^{\mathrm{a}}$} \\
\hline & \multicolumn{4}{|l|}{ After $24 \mathrm{~h}$} & \multicolumn{4}{|l|}{ After $48 \mathrm{~h}$} \\
\hline & Xylanase & Endoglucanase & $\begin{array}{l}\text { ß- } \\
\text { glucosidase }\end{array}$ & Filterpaperase & Xylanase & Endoglucanase & $\begin{array}{l}\text { ß- } \\
\text { glucosidase }\end{array}$ & Filterpaperase \\
\hline $\begin{array}{l}\text { Extracted xylan from } \\
\text { UTB }\end{array}$ & $25.16 \pm 0.02$ & $36.06 \pm 0.12$ & $35.8 \pm 0.04$ & $5.47 \pm 0.01$ & $17.59 \pm 0.05$ & $18.71 \pm 0.12$ & $26.13 \pm 0.04$ & $9.86 \pm 0.01$ \\
\hline $\begin{array}{l}\text { Extracted xylan from } \\
\mathrm{NaOH}+\mathrm{IL} \mathrm{TB}\end{array}$ & $16.19 \pm 0.04$ & $22.67 \pm 0.10$ & $24.57 \pm 0.06$ & $6.52 \pm 0.00$ & $12.32 \pm 0.04$ & $23.12 \pm 0.10$ & $23.32 \pm 0.02$ & $7.00 \pm 0.00$ \\
\hline $\mathrm{NaOH}+\mathrm{IL} \mathrm{TB}$ & $8.44 \pm 0.16$ & $32.92 \pm 0.13$ & $23.52 \pm 0.02$ & $7.92 \pm 0.02$ & $28.51 \pm 0.06$ & $67.42 \pm 0.13$ & $61.15 \pm 0.06$ & $6.04 \pm 0.00$ \\
\hline UTB & $15.6 \pm 0.49$ & $12.34 \pm 0.11$ & $14.3 \pm 0.01$ & $7 \pm 0.00$ & $4.38 \pm 0.00$ & $22.14 \pm 0.11$ & $12.34 \pm 0.01$ & $2.23 \pm .01$ \\
\hline Xylan & $20.24 \pm 0.01$ & $21.95 \pm 0.31$ & $34.49 \pm 0.25$ & $8.49 \pm 0.01$ & $13.02 \pm 0.01$ & $22.63 \pm 0.31$ & $18.91 \pm 0.03$ & $7.77 \pm 0.03$ \\
\hline CMC & $14.78 \pm 0.03$ & $12.15 \pm 0.05$ & $30.57 \pm 0.12$ & $9.86 \pm 0.03$ & $15.66 \pm 0.02$ & $32.53 \pm 0.03$ & $35.67 \pm 0.1$ & $9.19 \pm 0.02$ \\
\hline
\end{tabular}

${ }^{a}$ Xylan was extracted from untreated sugarcane bagasse (UTB) and alkali and ionic liquid pretreated ( $\left.\mathrm{NaOH}+\mathrm{IL} \mathrm{TB}\right)$ 

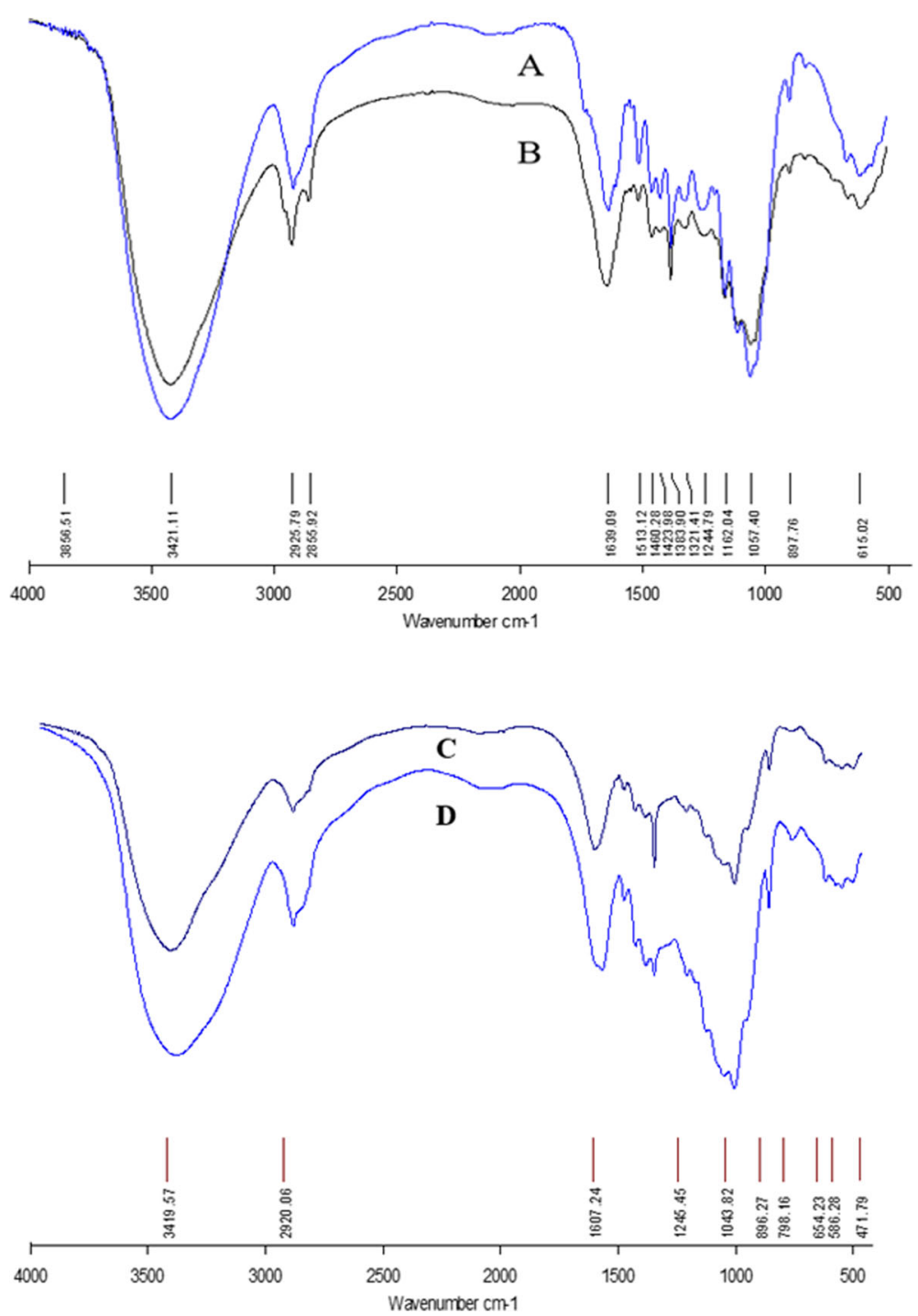

Fig. 3 FTIR spectra of (a) Alkali and ionic liquid pretreated sugarcane bagasse (b) Fermented sugarcane bagasse (c) Extracted xylan from untreated SB (d) Extracted xylan from pretreated SB

protons. Moreover, the hydroxymethylene protons of sugars also display signals in the same range. The fermented and $\mathrm{NaOH}+\mathrm{IL}$ pretreated bagasse did not show any peak in these regions. Similarly, the shifts at 4.1 and 4.4 ppm in both the samples represent the oxymethylene protons of xylose and arabinose residues.

\section{Discussion}

Microbial xylanases have become one of the most explored enzymes due to their wide commercial applications, therefore, the search for new and novel strains and/or xylanase has always remained at the core of industrial biotechnology. Amongst the four strains investigated in this study, the xylanolytic potential of $B$. borstelensis [31] and B. aestuarii [19] have been reported previously, whereas, $A$. thermoaerophilus has not been described earlier as xylanase producer.
Thermophilic nature of these strains was affirmed by their ability to produce more xylanase at higher temperatures that was in line with the findings by Chauhan et al. [19].

The aim of the study was to compare different pretreatment methods to SB and to adopt the most suitable method for xylanase production. The effectiveness of the pretreatment process can be assessed by enzyme titers [2]. Lignin is considered as a barrier that obstructs the access of enzymes thus, degradation of lignin may help cellulase and hemicellulases to act on their respective substrates [32]. Nerurker et al. [33] has previously studied the effect of different pretreatment methods for valorization of $\mathrm{SB}$ and the results proved that the chemical pretreatment valorized the SB and resulted in enhanced enzymatic saccharification. 
a

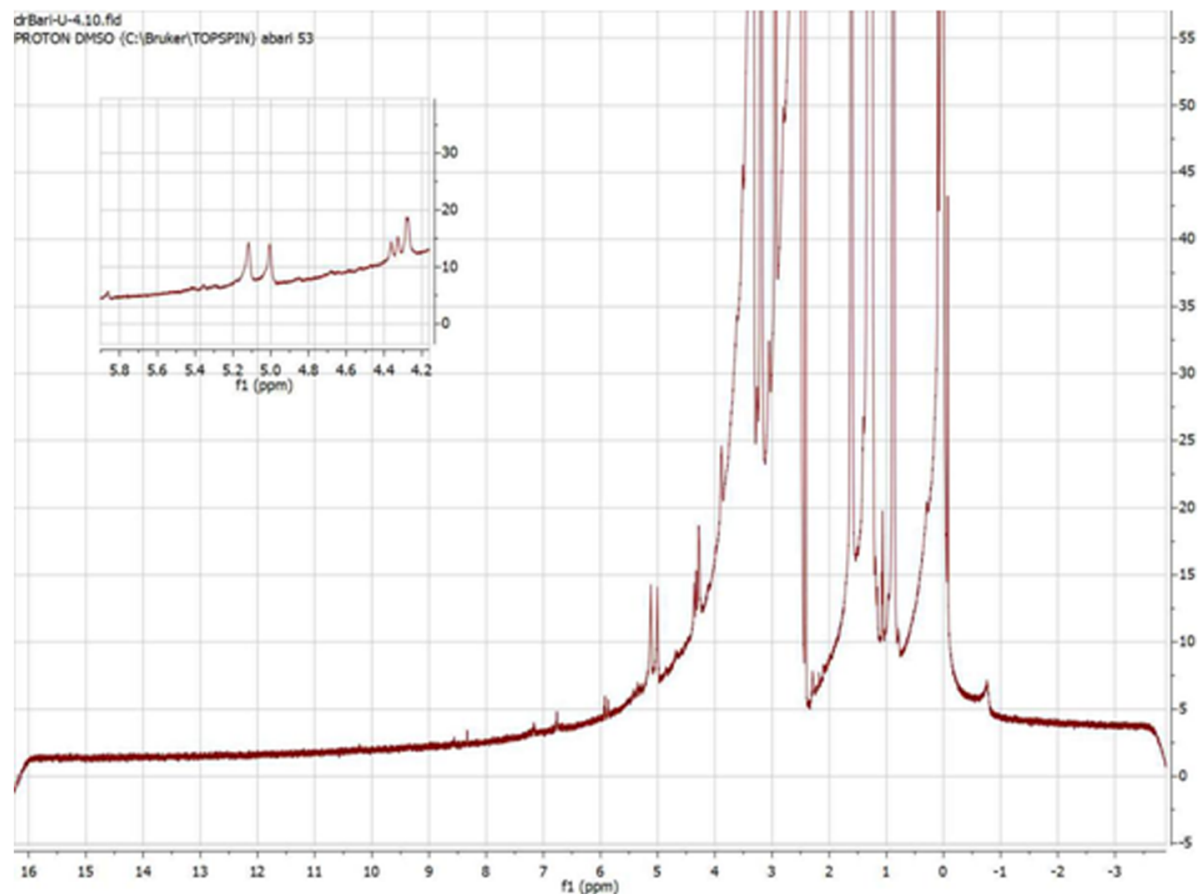

b

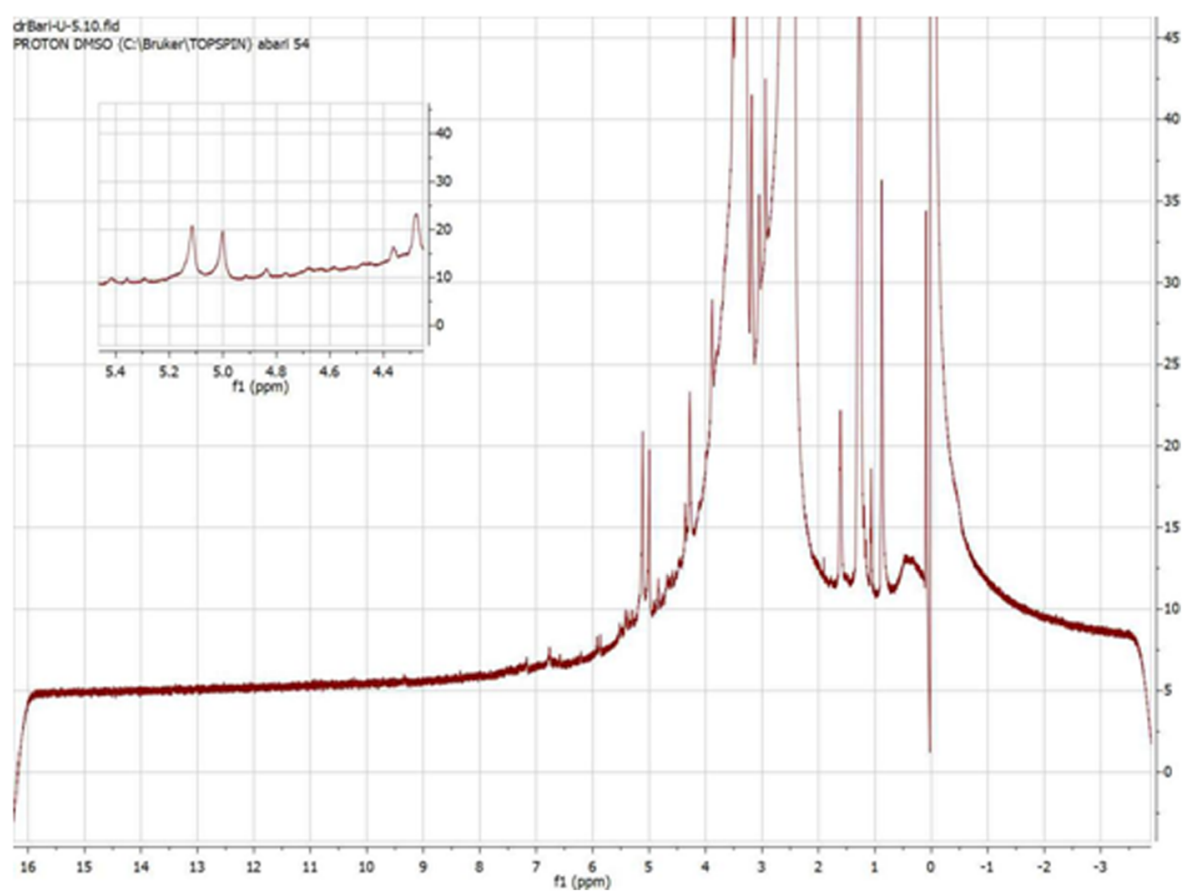

Fig. 4 Nuclear Magnetic Resonance (NMR) spectra of (a) alkali and ionic liquid (NaOH+IL) pretreated SB (b) spectra of fermented SB 
In this study, the effectiveness of pretreatment methods was correlated with the titers of xylanase obtained from the fermentation of pretreated SB by B. aestuarii UE25. The factors affecting xylanase production on pretreated SB were evaluated by a statistical method, PBD, that was found to be an effective tool to improve the production of microbial enzymes [34-36].

De Guilherme et al. [9] discussed disadvantages of using $\mathrm{H}_{2} \mathrm{O}_{2}$ as it resulted in lesser degree of delignification and production of considerable foam during the reaction that caused the loss of solid matter. Similar observations were recorded in this study for $\mathrm{H}_{2} \mathrm{O}_{2}$ pretreatment.

Whereas, $\mathrm{NaOH}$ pretreatment was found better than $\mathrm{H}_{2} \mathrm{SO}_{4}$ pretreatment in terms of xylanase production. Acid pretreatment degrades the ultrastructure of LC waste by hydrolyzing xylan along with a portion of cellulose which leads to the loss of valuable sugars, while $\mathrm{NaOH}$ removes the lignin layer without removing the polysaccharides in SB and increases the accessibility of the enzymes to hemicelluloses. Qadir et al. [37] compared the effectiveness of acid and alkaline pretreatment of SB to utilize it for the simultaneous production of cellulase and xylanase by a yeast co-culture and statistically proved suitability of alkali pretreated SB as compare to acid pretreatment.

In this study, the data obtained from the design 1 of PBD revealed that pretreatment of SB by $\mathrm{NaOH}$ followed by IL $(\mathrm{NaOH}+\mathrm{IL})$ was found to be the most suitable pretreatment method for higher xylanase productivity. The $\mathrm{NaOH}+\mathrm{IL}$ pretreatment of SB caused physical disruption of fibers and pith, the fibrils became more exposed by the removal of the superficial layer leading to structural alteration that interrupted the cross linking between cellulose, hemicellulose and lignin. Alkali primarily acts on lignin while IL modifies the crystalline shape of cellulose and hemicelluloses by breaking the hydrogen bonds in the structure of SB [38]. Methyltrioctylammonium consists of solvated chloride ions, therefore, has strong hydrogen-bonding basicity and is relatively more hydrophobic. In a previous report, quaternary ammonium IL was used for delignification of southern yellow pine wood at a high reaction temperature in dimethyl sulfoxide (DMSO) which is comparatively a toxic solvent [39]. In contrast, in this study the pretreatment was given at a lower temperature $\left(70^{\circ} \mathrm{C}\right)$; the use of ethanol instead of other more toxic solvent also makes this process greener. Moreover, the recyclability and reusability of IL is yet another advantage by which, the higher cost of IL can be compensated. Various techniques have been reported for recycling IL such as rotary evaporation [15], crystallization, liquid extraction, vacuum distillation, ion exchange nanofiltration, adsorption and salting out [40]. Ejaz et al. [41] recycled methyltrioctylammonium chloride for six times by evaporating ethanol from it retaining $70 \%$ xylanase productivity by recylcled IL pretreated SB. Hence, the effective pretreatment method for xylanase production was statistically confirmed by comparing the three designs by two-way ANOVA. It was observed that the model for design 1 was significant and ultimately was selected for further optimization through RSM.

RSM approaches furnish the actual value of every variable to be used optimally in a process [42]. Therefore, the significant factors (inoculum size, incubation time, temperature, agitation and $\mathrm{pH}$ ) influencing xylanase production by utilizing $\mathrm{NaOH}+\mathrm{IL}$ pretreated $\mathrm{SB}$ byB. aestuarii UE25 were investigated by BBD in RSM. Results showed that the best xylanase production was achieved when $7.03 \%$ inoculum size was used. As reported by Yoon et al. [43], an increase in inoculum size may initially enhance growth of the organism with subsequent decline in nutrients. Contrarily if lower inoculum size is transferred, organisms may put more efforts to colonize LC biomass resulting in a reduced enzyme production.

The effect of temperature on xylanase production by $B$. aestuarii UE25 was checked and optimal xylanase production was recorded at $59.8{ }^{\circ} \mathrm{C}$. The thermophilic conditions significantly lessen the chance of media contamination by mesophilic microorganism and the storage time can be extended without losing enzyme activity [44]; therefore, studies on xylanase production by $B$. aestuarii UE25 warrant merit.

The change in $\mathrm{pH}$ causes alterations in ionic interaction among amino acids of an enzyme that results in loss of the conformation of the active site of the enzyme, therefore, an optimum $\mathrm{pH}$ is required to maintain the functional shape of the enzyme [45]. In our study, the results suggest that enzyme production was maximal at an acidic $\mathrm{pH}$ of 5 . Researchers have found that breakdown of xylan in LC biomass is accelerated by acidic media which makes the substrate more sensitive and ultimately enzymes can work more efficiently [46]. Literature suggests that acidic xylanases have many potential industrial applications including in bio-bleaching, fruit juice clarification, or xylooligosachharides production [46].

The agitation of the fermentation medium was yet another significant factor. The amount of aeration and mixing of nutrients have been reported to affect the mass transfer and regulation of enzyme expression. In this study, maximum production of xylanase was recorded at an agitation of $141 \mathrm{rpm}$.

After analyzing the data and comparable response, an experimental design comprised of single run was proposed by the software. Experimental values (17.77 $\mathrm{IU} \mathrm{mL}^{-1}$ ) obtained under optimum conditions, in comparison to the predicted value $\left(20 \mathrm{IU} \mathrm{mL}^{-1}\right)$ indicated the validity of the model. The enzyme production obtained under optimized conditions in $\mathrm{BBD}$ was lower than the enzyme production obtained in PBD. PBD is used to identify significant factors by evaluating linear effects and interactions of factors. While BBD allows to consider quadratic effects and provides an accurate 
value of each significant factor and, therefore, results obtained from BBD could be different from PBD [47].

Positive interaction was observed between the incubation time and temperature. The xylanase production by B. aestuarii UE25 was significantly higher with increase in incubation time and temperature adjusting the inoculum size up to $10 \%$. However Yardimci and Cekmecelioglu [48] found a decrease in productivity with increase in inoculum size and reported $4 \%$ inoculum size for xylanase production.

Although the enzyme production kinetics showed an increasing pattern of xylanase production from 24 to 48 $h$, however the data for volumetric productivity $\left(\mathrm{Q}_{\mathrm{p}}\right)$ for xylanase illustrated that there was no significant increase in the xylanase titer in $48 \mathrm{~h}$ comparative to $24 \mathrm{~h}$. Hence, it can be perceived that it is not cost effective to continue the cultivation until $48 \mathrm{~h}$. Moreover, the design also presented $24 \mathrm{~h}$ as an appropriate duration for xylanase production. The duration of $24-48 \mathrm{~h}$ have previously been reported for xylanase production by Mrudula and Shyam [49] and Simphiwe et al. [50].

The SmF of xylan extracted from pretreated SB yielded 1.25 folds higher xylanase production than the commercially purified xylan after $24 \mathrm{~h}$ into fermentation. When the data for $48 \mathrm{~h}$ cultivation was compared, $\mathrm{NaOH}+\mathrm{IL}$ pretreated SB was found to be the most appropriate substrate. In this study, $45 \%$ xylan was extracted from pretreated SB which is closely related to the results reported by Hauli et al. [51] who recovered $49 \%$ of xylan from SB by a similar method. It is also imperative to note that the extracted $x y-$ lan has some cellulosic part and the co-expression of cellulase and xylanase has also been reported [52]. Therefore, production of EG, BGL and FPase was also detected. The data affirmed the cellulolytic nature of $B$. aestuarii UE25 [22] as much higher titers of cellulases were obtained. These findings assist the hypothesis stated by Han et al. [53] that a medium containing hemicelluloses gives rise to coordinated expression of cellulase and hemicellulase. The production of xylanase in cellulose containing medium indicates the presence of cellulose. It can also be attributed to the fact that ACEII, a cellulase regulator, also influences xylanase regulation [2]. Xylanase production reported in this study is significantly higher than the previous reports $[37,54]$. Although, further improvement could be done by adopting other methods such as recombinant technology.

The SEM analysis of SB showed significant changes in the pretreated and fermented SB samples. Untreated samples showed rigid morphology of SB. Similar observation was reported by Chandel et al. [24]. Applying $\mathrm{NaOH}+\mathrm{IL}$ pretreatment prior to enzymatic hydrolysis induced significant alteration in the structure of the SB, allowing an increased production of xylanase. Similar observations were reported by Ejaz et al. [55] where alkali and IL pretreatment resulted in destruction of SB structure. After SmF, the enzymatic degradation of SB was more prominent due to further destruction and separation of fibers making the structure more fragile [22].

The removal of lignin in pretreated SB was also confirmed by changes in the region $1260.93 \mathrm{~cm}^{-1}$ and from $1425.39 \mathrm{~cm}^{-1}$ to $1511.93 \mathrm{~cm}^{-1}$ in FTIR spectra [23]. The enzymatic hydrolysis of cellulosic and hemicellulosic moieties was highlighted by the increased intensity at 1057 $\mathrm{cm}^{-1}$ and $1162.04 \mathrm{~cm}^{-1}$ [26]. Since SB is rich (20\%) in arabinoxylan [56], therefore, a sharp band at $1043 \mathrm{~cm}^{-1}$ [28] was visible in the spectra of extracted xylan from untreated SB. After xylan extraction from pretreated SB, high purity xylanfibers were obtained which demonstrate that the pretreatment and extraction protocol were suitable and efficient. Whereas, the band at $896.27 \mathrm{~cm}^{-1}$ [23] was more intense in the pretreated SB which indicated that xylan yield was better from pretreated SB compared to untreated SB as only a slight change was observed in the region of $894.84 \mathrm{~cm}^{-1}$ for the later substrate.

The NMR studies confirmed the lignin ratio in untreated bagasse in the range of 6.0-6.5 while the lower absorbance in these regions in $\mathrm{NaOH}+\mathrm{IL}$ treated $\mathrm{SB}$ indicated the removal of the lignin part [29]. Similarly, the shifts at 4.1 and $4.4 \mathrm{ppm}$ in pretreated samples are representing the oxymethylene protons of xylose and arabinose residues [28].

\section{Conclusions}

From the findings of present study, it can be concluded that thermophilic bacterial strain (Bacillus aestuarii UE25) produced higher titers of xylanase by utilizing alkali and IL pretreated SB which is not reported earlier. Sequential pretreatment of SB with alkali followed by methyltrioctylammonium chloride was found statistically more significant than acid, alkaline or hydrogen peroxide pretreatment. The analyses (SEM, FTIR and NMR) also support the strategy to use IL for SB pretreatment as it is evident by structural changes in SB such as lignin removal and xylan accessibility. The presence of xylan extracted from SB in the production medium yielded higher xylanase productivity than that of commercially available xylan. It is expected that the present study will provide an opportunity for a sustainable sugarcane industry to use low-cost agro-waste (SB) for xylanase production by $B$. aestuarii UE25.

\section{Materials and methods}

\section{Pretreatment of sugarcane bagasse}

SB was provided by a local industry. Residual sugars were removed by excessive washing with tap water followed by drying at $60^{\circ} \mathrm{C}$ for overnight up to $0 \%$ of moisture content. The dried substrate was ground to $300 \mu \mathrm{m}$ mesh size using coffee bean grinder (Anex TS630 ). This untreated SB was used for different chemical pretreatments. 
For alkaline and acid pretreatment, powdered SB was soaked in $1 \%(\mathrm{w} / \mathrm{v})$ sodium hydroxide $(\mathrm{NaOH})$ or sulfuric acid $\left(\mathrm{H}_{2} \mathrm{SO}_{4}\right)$, respectively, at the rate of $50 \mathrm{ml} \mathrm{g}^{-1}$ and left at room temperature for $24 \mathrm{~h}$ [37]. Any residual acid or alkali was neutralized by repeated washing with tap water. The pretreated SB was then oven dried at $60^{\circ} \mathrm{C}$ for $24 \mathrm{~h}$.

Hydrogen peroxide $\left(\mathrm{H}_{2} \mathrm{O}_{2}\right)$ pretreatment of $\mathrm{SB}$ was performed by swamping $4 \%(\mathrm{w} / \mathrm{v})$ aqueous suspension of SB in a $7.35 \%(\mathrm{v} / \mathrm{v})$ hydrogen peroxide solution. The slurry was stirred using a magnetic stirrer at $100 \mathrm{rpm}$ for $1 \mathrm{~h}$ at room temperature [9] and filtered with Whatman No. 1 filter paper. The remaining solid fraction was washed and stored at $4{ }^{\circ} \mathrm{C}$.

Ionic Liquid (IL) pretreatment was carried out by loading SB in methytrioctylammonium chloride (Merck, Germany) at the ratio of $1: 15$ at $70{ }^{\circ} \mathrm{C}$ for $30 \mathrm{~min}$. After filtration, washed thrice with ethanol and thrice with distilled water [22] and dried. For a combination of alkaline-ionic liquid $(\mathrm{NaOH}+\mathrm{IL})$ pretreatment, alkali pretreated SB was further pretreated with the IL as mentioned. Ethanol was evaporated from the reused IL and recycled IL was used without further purification [22].

\section{Bacterial strain and inoculum preparation}

Initially four thermophilic strains, namely Aneurinibacillus thermoaerophilus UE1, Brevibacillus borstelensis UE10 and UE27 and B. aestuarii UE25 were screened for xylanase production. The strains were obtained from the culture collection of the department of Microbiology, University of Karachi, purified and maintained on Nutrient Agar (Oxoid, UK). The inoculum was prepared by transferring an isolated colony into Nutrient broth (Oxoid, UK) and incubated at $60^{\circ} \mathrm{C}$ for $48 \mathrm{~h}$ at $150 \mathrm{rpm}$. It was transferred to the appropriate production medium by maintaining $\mathrm{OD}_{600}$ at 0.3 .

\section{Screening of bacteria for xylanase production}

Four thermophilic bacterial strains were screened for xylanase production as mentioned by Shariq and Sohail [54] with slight modification. The inoculum was transferred to mineral salt medium (MSM) $\left[\mathrm{g} \mathrm{L}^{-1}\right.$ of $\mathrm{K}_{2} \mathrm{HPO}_{4}$ 1, $\left(\mathrm{NH}_{4}\right)_{2} \mathrm{SO}_{4} 1, \mathrm{MgSO}_{4} \cdot 7 \mathrm{H}_{2} \mathrm{O} 0.02, \mathrm{CaCl}_{2} 1, \mathrm{FeCl}_{3}$ 0.02] which contained $1 \%$ untreated or pretreated $\mathrm{SB}$ and separately incubated at $50^{\circ} \mathrm{C}, 55^{\circ} \mathrm{C}$ or $60^{\circ} \mathrm{C}$ for $48 \mathrm{~h}$. After $48 \mathrm{~h}$, the cells were harvested by centrifugation at 5000 $\mathrm{x} g$ for $10 \mathrm{~min}$ and supernatant was served as a source of crude xylanase preparation.

\section{Fermentation of alkali and IL pretreated SB by $B$. aestuarii UE25}

Since $B$. aestuarii UE25 yielded higher titers of xylanase so it was selected to study the effect of various factors on its xylanase production under submerged fermentation $(\mathrm{SmF})$ of SB. In the initial step of optimization, PBD was employed. Three separate PBDs (for $\mathrm{NaOH} / \mathrm{H}_{2} \mathrm{SO}_{4}$ pretreated $\mathrm{SB}, \mathrm{H}_{2} \mathrm{O}_{2}$ /untreated $\mathrm{SB}$ and $\mathrm{IL} / \mathrm{NaOH}+\mathrm{IL}$ pretreated $\mathrm{SB}$ ), each consisting of 12 different experiments were generated using Minitab18 software. Eight factors (Supplementary Table S1, online material) were screened at two levels including temperature $\left(55,60^{\circ} \mathrm{C}\right), \mathrm{pH}(5,7)$, medium (Mineral salt medium, MSM, with $0.5 \%$ glucose or MSM with $0.5 \%$ glucose and peptone), inoculum size (5, $10 \%)$, incubation time $(24,48 \mathrm{~h}$ ), pretreatment (with chemical or untreated), substrate concentration $(1 \%$ or $2 \%)$ and agitation (with or without shaking).

After completion of the experiments, cell-free culture suspensions (CFCS) were collected and assayed for xylanase activity and $\mathrm{IU} \mathrm{mL}^{-1}$ of the enzyme was taken as response. All the experimental runs of PBD were analyzed whereupon five factors showed up as significant variables (temperature, agitation, $\mathrm{pH}$, incubation timeand inoculum size) affecting the production of xylanase under SmF of SB. Optimization of these significant factors at three levels $(-1,0,+1)$ was carried out by adopting Box-Behnken design (BBD) in Response surface method (RSM) approach. The experimental runs of 46 (as generated by Minitab 18 software) were carried out in triplicate and the mean values were used for analysis. To investigate kinetics of xylanase production, $\mathrm{SmF}$ of SB was carried out under optimized conditions and aliquots were withdrawn intermittently. After centrifugation, the CFCS was used to determine xylanase activity and $\mathrm{pH}$. The data was used to determine volumetric productivity after $24 \mathrm{~h}$ and $48 \mathrm{~h}$.

\section{Extraction of xylan}

Xylan was extracted from untreated and $\mathrm{NaOH}+\mathrm{IL}$ pretreated SB [51] and was used in the medium to produce xylanase by $B$. aestuarii UE25. Briefly, SB was immersed in $10 \%$ sodium hydroxide at the ratio of $1: 10$ at $60^{\circ} \mathrm{C}$ for overnight with constant agitation and then steamed for $3 \mathrm{~h}$ at $100^{\circ} \mathrm{C}$. The suspension was centrifuged at 10,000 $\mathrm{xg}$ for $15 \mathrm{~min}$ and the pellet was acidified with $12 \mathrm{~N}$ hydrochloric acid to adjust the $\mathrm{pH}$ as 5.0. Xylan was precipitated by adding 1.5 volume of $95 \%$ ethanol and separated by centrifugation at $6000 \mathrm{xg}$ for $10 \mathrm{~min}$. The extracted xylan was dried in a hot air oven at $55^{\circ} \mathrm{C}$ for $4 \mathrm{~h}$, weighed and stored at room temperature. The true recovery of xylan was calculated using the following formula as reported by Hauli et al. [51]:

True recovery $(\%)=$ dry weight of extracted xylan $(g) /$ weight of the SB sample $(\mathrm{g}) \times 100$.

The extracted xylan was fermented by $B$. aestuarii UE25 and the results were compared with beechwood xylan (Sigma, Aldrich).

\section{Enzyme assays}

The enzyme preparation was assayed for xylanase, endoglucanase, $\beta$-glucosidase and filter-paperase activities by 
adding $25 \mu \mathrm{L}$ of crude enzyme to $25 \mu \mathrm{L}(0.5 \% \mathrm{w} / \mathrm{v})$ beechwood xylan, carboxymethyl cellulose (CMC), salicin (Sigma, Aldrich) or filter paper strip (of $1.5 \times 3$ $\mathrm{mm})$, respectively. The reaction mixture was incubated in a water bath at $60^{\circ} \mathrm{C}$ for $15 \mathrm{~min}$. The reaction was stopped by adding $150 \mu \mathrm{L}$ dinitrosalicylic acid (DNS) reagent and boiled for $5 \mathrm{~min}$. After cooling on ice, $720 \mu \mathrm{L}$ of distilled water was added. $\mathrm{OD}_{540}$ was measured against blank and compared with the calibration curve of glucose or xylose.

One International unit of the enzyme activity was defined as $1 \mu \mathrm{mol}$ of glucose or xylose produced by $1 \mathrm{~mL}$ of the enzyme per min under the standard assay conditions.

\section{Analysis of structural changes in SB}

Samples of untreated, $\mathrm{NaOH}+\mathrm{IL}$ treated and fermented SB were analyzed at $10 \mathrm{kV}$ using Analytical Scanning Electron Microscope JSM-6380 A, JEOL USA.

FTIR analysis of heat dried samples was carried out by taking spectra on JASCO FTIR-4200, whereas Proton Nuclear magnetic resonance (1H NMR) spectroscopy was performed by using Bruker AV-700 MHz spectrometer operating at $700 \mathrm{MHz}$ in DMSO-d6 solutions. The ppm $(\delta)$ represents chemical shifts referenced to the signals relevant to DMSO d6.

\section{Supplementary Information}

The online version contains supplementary material available at https://doi. org/10.1186/s12896-020-00657-4.

Additional file 1: Table S1. List of factors screened by Plackett-Burman design for xylanase production by Bacillus aestuarii UE25. Table S2. Screening of thermophilic bacteria for xylanase production by using sugarcane bagasse. Table S3. Screening of Bacillus aestuarii UE25 for xylanase production at $37^{\circ} \mathrm{C}$. Table S4. Regression coefficient and $P$ values of xylanase by $\mathrm{NaOH}+\mathrm{IL}$ Plackett-Burman Design. Table S5. Analysis of Variance for xylanase production by Bacillus aestuarii UE25 by $\mathrm{NaOH}+\mathrm{IL}$ Plackett-Burman Design. Table S6. Regression coefficient and P values of xylanase by Akali/Acid Plackett-Burman Design. Table S7. Analysis of Variance for xylanase production by Bacillus aestuarii UE25 by Alkali/Acid Plackett-Burman Design. Table S8. Regression coefficient and $P$ values of xylanase by $\mathrm{H}_{2} \mathrm{O}_{2} /$ Untreated Plackett-Burman Design. Table S9. Analysis of Variance for xylanase production by Bacillus aestuarii UE25 by $\mathrm{H}_{2} \mathrm{O}_{2} / \mathrm{Un}$ treated Plackett-Burman Design. Table S10. Two-Way Analysis of Variance for comparison of different Plackett-Burman experimental designs for xylanase production. Table S11. Analysis of variance of Box-Behnken design for xylanase production by Bacillus aestuarii UE25. Fig. S1. Pareto Chart of the standardized effects showing the significant factors. Fig. S2. Scanning electron micrographs of various samples of SB (a) Untreated SB (b) $\mathrm{NaOH}+\mathrm{IL}$ pretreated SB (c) Fermented SB with Bacillus aestuarii UE25.

\footnotetext{
Abbreviations

BBD: Box-behnken design; BGL: B-Glucosidase; CFCS: Cell-free culture suspensions; CMC: Carboxymethyl cellulose; DMSO: Dimethyl sulfoxide; DNS: Dinitrosalicylic acid; EG: Endoglucanase; FPase: Filter-paperase; FTIR: Fourier transform infrared spectroscopy; $\mathrm{H}_{2} \mathrm{O}_{2}$ : Hydrogen peroxide; $\mathrm{H}_{2} \mathrm{SO}_{4}$ : Sulfuric acid; IL: Ionic liquid; LC: Lignocellulose; MSM: Mineral salt medium; $\mathrm{NaOH}$ : Sodium hydroxide; $\mathrm{NaOH}+\mathrm{IL}$ : Alkaline-ionic liquid; NMR: Nuclear magnetic resonance; PBD: Plackett-burman design; RSM: Response surface method; SB: Sugarcane bagasse; SmF: Submerged fermentation; UTB: Untreated bagasse
}

\section{Acknowledgements}

This work was supported by financial assistance from the Higher Education Commission of Pakistan to RR under Aghaz e Huqooq e Balochistan Scheme Indigenous Scholarship Program.

\section{Authors' contributions}

MS conceived the idea and designed the study. RR, UE, JL and LW performed experiments. FIA, IAH and AB performed data analysis and interpreted the data. RR, UE, PF and MS wrote the manuscript. All the authors reviewed the manuscript. The author (s) read and approved the final manuscript.

\section{Funding}

This work was supported by financial assistance from the Higher Education Commission of Pakistan to RR under Aghaz e Huqooq e Balochistan Scheme Indigenous Scholarship Program.

\section{Availability of data and materials}

The data associated with this manuscript has been provided in a supplementary file available online. The raw data can be obtained from the corresponding author.

Ethics approval and consent to participate

Not applicable.

\section{Consent for publication}

Not applicable.

\section{Competing interests}

The authors declare that there is no conflict of interest.

\section{Author details}

${ }^{1}$ Department of Microbiology, University of Karachi, 75270, Karachi, Pakistan. ${ }^{2}$ Department of Microbiology, University of Balochistan, Quetta, Pakistan. ${ }^{3}$ Department of Chemistry, University of Karachi, 75270, Karachi, Pakistan. ${ }^{4}$ Department of Pharmaceutical Chemistry, College of Pharmacy, King Saud University, Riyadh, Saudi Arabia. ${ }^{5}$ State Key Laboratory of Marine Resource Utilization in South China Sea, Hainan University, Haikou 570228, China.

Received: 14 September 2020 Accepted: 11 November 2020

Published online: 09 December 2020

\section{References}

1. Loh YR, Sujan D, Rahman ME, Das CA. Review sugarcane bagasse - the future composite material: a literature review. Resour Conserv Recycl. 2013; 75:14-22. https://doi.org/10.1016/j.resconrec.2013.03.002.

2. Camassola M, Dillon AJP. Effect of different pretreatment of sugar cane bagasse on cellulase and xylanases production by the mutant penicillium echinulatum 9A02S1 grown in submerged culture. Biomed Res Int. 2014; 2014. https://doi.org/10.1155/2014/720740.

3. Restrepo-Serna DL, Martínez-Ruano JA, Cardona-Alzate CA. Energy efficiency of biorefinery schemes using sugarcane bagasse as raw material. Energies. 2018;11(12):3474. https://doi.org/10.3390/en11123474.

4. Duque SH, Cardona CA, Moncada J. Techno-economic and environmental analysis of ethanol production from 10 agroindustrial residues in Colombia. Energy Fuels. 2015;29(2):775-83. https://doi.org/10.1021/ef5019274.

5. Edye LA, Doherty WOS, Blinco JA, Bulloc GE. The sugarcane biorefinery: energy crops and processes for the production of liquid fuels and renewable commodity chemicals. Int Sugar J. 2006;108(1285):19-27.

6. Moncada J, El-Halwagi MM, Cardona CA. Techno-economic analysis for a sugarcane biorefinery: Colombian case. Bioresour Technol. 2013;135:533-43. https://doi.org/10.1016/j.biortech.2012.08.137.

7. Raj T, Gaur R, Lamba BY, Singh N, Gupta RP, Kumar R, et al. Characterization of ionic liquid pretreated plant cell wall for improved enzymatic digestibility. Bioresour Technol. 2017;2018(249):139-45. https://doi.org/10. 1016/j.biortech.2017.09.202.

8. Widjaja A, Agnesty SY, Sangian HF, Gunawan S. Application of ionic liquid [DMIM] DMP pretreatment in the hydrolysis of sugarcane bagasse for biofuel production. Bull Chem React Eng Catal. 2015;10:70-7. https://doi. org/10.9767/bcrec.10.1.7143.70-77. 
9. De Guilherme AA, Dantas PVF, Soares JCJ, Dos Santos ES, Fernandes FAN, De Macedo GR. Pretreatments and enzymatic hydrolysis of sugarcane bagasse aiming at the enhancement of the yield of glucose and xylose. Braz J Chem Eng. 2017;34:937-47. https://doi.org/10.1590/0104-6632.20170344s20160225.

10. Ejaz U, Sohail M. Ionic liquids: green solvent for biomass pretreatment. In: Nanotechnology-Based Industrial Applications of lonic Liquids. 2020. p. 27 36. doi:https://doi.org/10.1007/978-3-030-44995-7_2.

11. Chambon CL, Mkhize TY, Reddy P, Brandt-Talbot A, Deenadayalu N, Fennell PS, et al. Pretreatment of south African sugarcane bagasse using a low-cost protic ionic liquid: a comparison of whole, depithed, fibrous and pith bagasse fractions. Biotechnol Biofuels. 2018;11:1-16. https:/doi.org/10.1186/s13068-018-1247-0.

12. Ávila PF, Franco Cairo JPL, Damasio A, Forte MBS, Goldbeck R. Xylooligosaccharides production from a sugarcane biomass mixture: Effects of commercial enzyme combinations on bagasse/straw hydrolysis pretreated using different strategies. Food Res Int. 2020; 128:108702. doi. org/https://doi.org/10.1016/j.foodres.2019.108702.

13. Haghighi Mood S, Hossein Golfeshan A, Tabatabaei M, Salehi Jouzani G, Najafi GH, Gholami M, et al. Lignocellulosic biomass to bioethanol, a comprehensive review with a focus on pretreatment. Renew Sust Energ Rev. 2013;27:77-93. https://doi.org/10.1016/j.rser.2013.06.033.

14. Ghandi K. A review of ionic liquids, their limits and applications. Green Sustain Chem. 2014;4. https://doi.org/10.4236/gsc.2014.41008.

15. Ejaz U, Muhammad S, Hashmi IA, Ali FI, Sohail M. Utilization of methyltrioctylammonium chloride as new ionic liquid in pretreatment of sugarcane bagasse for production of cellulase by novel thermophilic bacteria. J Biotechnol. 2020;317(February):34-8. https://doi.org/10.1016/j.jbiotec.2020.04.013.

16. Sporck D, Reinoso FAM, Rencoret J, Gutiérrez A, Del Rio JC, Ferraz A, et al. Xylan extraction from pretreated sugarcane bagasse using alkaline and enzymatic approaches. Biotechnol Biofuels. 2017;10:1-11. https://doi.org/10. 1186/s13068-017-0981-z

17. Naseeb S, Sohail M, Ahmad A, Khan SA. Production of xylanases and cellulases by aspergillus fumigatus ms 16 using crude lignocellulosic substrates. Pakistan J Bot. 2015;47:779-84.

18. Bibra M, Kunreddy V, Sani R. Thermostable xylanase production by geobacillus sp. strain DUSELR13, and its application in ethanol production with lignocellulosic biomass. Microorganisms. 2018;6(3):93. https://doi.org/ 10.3390/microorganisms6030093.

19. Chauhan S, Seth CA, Seth A. Bioprospecting thermophilic microorganisms from hot springs of western himalyas for xylanase production and its statistical optimization by using response surface methodology. J Pure Appl Microbiol. 2015;9:1417-28.

20. van Zyl C, Prior BA, du Preez JC. Acetic acid inhibition of d-xylose fermentation by Pichia stipitis. Enzym Microb Technol. 1991;13(1):82-6. https://doi.org/10.1016/0141-0229(91)90193-E.

21. Singh V, Das D. Potential of hydrogen production from biomass. In: Science and Engineering of Hydrogen-Based Energy Technologies: Hydrogen Production and Practical Applications in Energy Generation. 2018. p. 123164. doi:https://doi.org/10.1016/B978-0-12-814251-6.00003-4.

22. Ejaz U, Muhammad S, Ali Fl, Hashmi IA, Sohail M. Methyltrioctylammonium chloride mediated removal of lignin from sugarcane bagasse for themostable cellulase production. Int J Biol Macromol. 2019;140:1064-72. https://doi.org/10.1016/j.ijbiomac.2019.08.206.

23. Xu F, Sun JX, Liu CF, Sun RC. Comparative study of alkali- and acidic organic solvent-soluble hemicellulosic polysaccharides from sugarcane bagasse. Carbohydr Res. 2006;341(2):253-61. https://doi.org/10.1016/j.carres.2005.10.019.

24. Chandel AK, Antunes FAF, Anjos V, Bell MJV, Rodrigues LN, Polikarpov I, et al. Multi-scale structural and chemical analysis of sugarcane bagasse in the process of sequential acid-base pretreatment and ethanol production by Scheffersomyces shehatae and Saccharomyces cerevisiae. Biotechnol Biofuels. 2014;7(1):63. https://doi.org/10.1186/1754-6834-7-63.

25. Buranov AU, Mazza G. Extraction and characterization of hemicelluloses from flax shives by different methods. Carbohydr Polym. 2010;79(1):17-25. https://doi.org/10.1016/j.carbpol.2009.06.014

26. Sun XF, Sun RC, Fowler P, Baird MS. Isolation and characterisation of cellulose obtained by a two-stage treatment with organosolv and cyanamide activated hydrogen peroxide from wheat straw. Carbohydr Polym. 2004; 55(4):379-391. doi.org/https://doi.org/10.1016/j.carbpol.2003.10.004.

27. Peng F, Ren JL, Xu F, Bian J, Peng P, Sun RC. Comparative study of hemicelluloses obtained by graded ethanol precipitation from sugarcane bagasse. J Agric Food Chem. 2009;57(14):6305-17. https://doi.org/10.1021/ jf900986b.
28. Bian J, Peng F, Peng XP, Xu F, Sun RC, Kennedy JF. Isolation of hemicelluloses from sugarcane bagasse at different temperatures: structure and properties. Carbohydr Polym. 2012;88(2):638-45. https://doi.org/10. 1016/j.carbpol.2012.01.010

29. Wang K, Jiang JX, Xu F, Sun RC. Influence of steaming pressure on steam explosion pretreatment of Lespedeza stalks (Lespedeza crytobotrya): part 1. Characteristics of degraded cellulose. Polym Degrad Stab. 2009;94(9):137988. https://doi.org/10.1016/j.polymdegradstab.2009.05.019.

30. Saha K, Dwibedi P, Ghosh A, Sikder J, Chakraborty S, Curcio S. Extraction of lignin, structural characterization and bioconversion of sugarcane bagasse after ionic liquid assisted pretreatment. 3 Biotech. 2018;8(8):374. https://doi. org/10.1007/s13205-018-1399-4.

31. Budhathoki $U$, Thapa P, Poluri E. Medium optimization of production of xylanase by solid state fermentation from Brevibacillus borstelensis - MTCC 9874 isolated from soil sample of eastern Nepal. Malays J Microbiol. 2011;7: 83-91. https://doi.org/10.21161/mjm.27310.

32. Pereira PHF, Voorwald HCJ, Cioffi MOH, Mulinari DR, da Luz SM, da Silva MLCP. Sugarcane bagasse pulping and bleaching: Thermal and chemical characterization. BioResources. 2011;6(3):2471-82. https://doi.org/10.15376/ biores.6.3.2471-2482

33. Thite VS, Nerurkar AS. Valorization of sugarcane bagasse by chemical pretreatment and enzyme mediated deconstruction. Sci Rep. 2019;9(1):1-4. https://doi.org/10.1038/s41598-019-52347-7.

34. Ejaz U, Ahmed A, Sohail M. Statistical optimization of immobilization of yeast cells on corncob for pectinase production. Biocatal Agric Biotechnol. 2018;14(April):450-6. https://doi.org/10.1016/j.bcab.2018.04.011.

35. Tariq R, Ansari I, Qadir F, Ahmed A, Shariq M, Zafar U, et al. Optimization of endoglucanase production from thermophilic strain of Bacillus licheniformis RT-17 and its application for saccharification of sugarcane bagasse. Pakistan J Bot. 2018:50:807-16

36. Maan, P., Bharti, A. K., Gautam, S., \& Dutt D. Screening of Important Factors for Xylanase and Cellulase Production from the Fungus C. cinerea RM-1. 2016;11:8269-76.

37. Qadir F, Shariq M, Ahmed A, Sohail M. Evaluation of a yeast co-culture for cellulase and xylanase production under solid state fermentation of sugarcane bagasse using multivariate approach. Ind Crops Prod. 2018; 123(July):407-15. https://doi.org/10.1016/j.indcrop.2018.07.021.

38. Yoon LW, Ngoh GC, May Chua AS, Hashim MA. Comparison of ionic liquid, acid and alkali pretreatments for sugarcane bagasse enzymatic saccharification. J Chem Technol Biotechnol. 2011;86:1342-8. https://doi.org/ 10.1002/jctb.2651.

39. Ali SS, Wu J, Xie R, Zhou F, Sun J, Huang M. Screening and characterizing of xylanolytic and xylose-fermenting yeasts isolated from the wood-feeding termite, Reticulitermes chinensis. PLoS One. 2017;12(7):e0181141. https://doi. org/10.1371/journal.pone.0181141.

40. Seader JD, Ernest J. Henley. Separation-process-principles-with-applicationsusing-process-simulators. 2006

41. Ejaz U, Muhammad S, Imran F, Ali I, Sohail M. Cellulose extraction from methyltrioctylammonium chloride pretreated sugarcane bagasse and its application. Int J Biol Macromol. 2020;165:11-7. https://doi.org/10.1016/j.jibiomac.2020.09.151.

42. Ahmed A, Khan MN, Ahmad A, Khan SA, Sohail M. Optimization of pectinase production from geotrichum candidum AA15 using response surface methodology. Pakistan J Bot. 2019;51:743-50. https://doi.org/10. 30848/PJB2019-2(41.

43. Yoon LW, Ang TN, Ngoh GC, Chua ASM. Fungal solid-state fermentation and various methods of enhancement in cellulase production. Biomass Bioenergy. 2014;67:319-38. https://doi.org/10.1016/j.biombioe.2014.05.013.

44. Gomes E, Souza AR De, Orjuela GL, Silva R Da, Oliveira TB De, Rodrigues A. Applications and Benefi ts of Thermophilic Microorganisms and Their Enzymes for Industrial Biotechnology. 2016. p. 459-492. doi:https://doi.org/ 10.1007/978-3-319-27951-0_21.

45. Okaiyeto K, Nwodo UU, Okoli SA, Mabinya LV, Anthony I. Implications for public health demands alternatives to inorganic and synthetic flocculants: bioflocculants as important candidates. Microbiologyopen. 2016;5(2):177211. https://doi.org/10.1002/mbo3.334.

46. Dey P, Roy A. Molecular structure and catalytic mechanism of fungal family $\mathrm{G}$ acidophilic xylanases. 3. Biotech. 2018:8:1-13. https://doi.org/10.1007/ s13205-018-1091-8.

47. Ashok A, Kumar DS. Different methodologies for sustainability of optimization techniques used in submerged and solid state fermentation. 3 Biotech. 2017;7(5):301. https://doi.org/10.1007/s13205-017-0934-Z. 
48. Yardimci GO, Cekmecelioglu D. Assessment and optimization of xylanase production using co-cultures of Bacillus subtilis and Kluyveromyces marxianus. 3. Biotech. 2018;8:1-10. https://doi.org/10.1007/s13205-018-1315-y.

49. Mrudula S, Shyam N. Immobilization of bacillus megaterium mtcc 2444 by caalginate entrapment method for enhanced alkaline protease production. Braz Arch Biol Technol. 2012;55(1):135-44. https://doi.org/10.1590/S151689132012000100017.

50. Simphiwe PB, Ademola OO, Balakrishna P. Sawdust and digestive bran as cheap alternate substrates for xylanase production. Afr J Microbiol Res. 2011;5:742-52. https://doi.org/10.5897/ajmr10.366.

51. Hauli I, Sarkar B, Mukherjee T, Chattopadhyay A, Mukhopadhyay SK. Alkaline extraction of xylan from agricultural waste, for the cost effective production of xylooligosaccharides, using thermoalkaline xylanase of thermophilic Anoxybacillus sp. Ip-C Int J Pure Appl Biosci. 2013;1(6):126-31.

52. Prem Anand AA, Sripathi K. Digestion of cellulose and xylan by symbiotic bacteria in the intestine of the Indian flying fox (Pteropus giganteus). Comp Biochem Physiol A Mol Integr Physiol. 2004;139(1):65-9. https://doi.org/10. 1016/j.cbpb.2004.07.006.

53. Han SO, Yukawa H, Inui M, Doi RH. Transcription of Clostridium cellulovorans cellulosomal cellulase and hemicellulase genes. J Bacteriol. 2003;185:2520-2527. doi.org/https://doi.org/10.1128/JB.185.8.2520-2527.2003.

54. Shariq M, Sohail M. Application of Candida tropicalis MK-160 for the production of xylanase and ethanol. J King Saud Univ Sci. 2019;31(4):118994. https://doi.org/10.1016/j.jksus.2018.04.009.

55. Ejaz U, Sohail M. Supporting role of lignin in immobilization of yeast on sugarcane bagasse for continuous pectinase production. J Sci Food Agric. 2020. https://doi.org/10.1002/jsfa.10764.

56. Mellinger-Silva C, Simas-Tosin FF, Schiavini DN, Werner MF, Baggio CH, Pereira IT, et al. Isolation of a gastroprotective arabinoxylan from sugarcane bagasse. Bioresour Technol. 2011;102(22):10524-8. https://doi.org/10.3390/ su8111168.

\section{Publisher's Note}

Springer Nature remains neutral with regard to jurisdictional claims in published maps and institutional affiliations.

Ready to submit your research? Choose BMC and benefit from:

- fast, convenient online submission

- thorough peer review by experienced researchers in your field

- rapid publication on acceptance

- support for research data, including large and complex data types

- gold Open Access which fosters wider collaboration and increased citations

- maximum visibility for your research: over $100 \mathrm{M}$ website views per year

At $\mathrm{BMC}$, research is always in progress.

Learn more biomedcentral.com/submissions 